دراسات كيميائية وتغذوية صحية علي الفئران المصابة بالسمنة باستخدام أعشاب الراوند والقتاده

$$
\text { إعداد }
$$

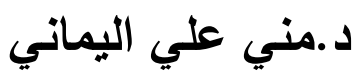

كلية التربية- قسم التربية الأسرية- جامعة أم القري- مكة المكرمة moony120@hotmail.com

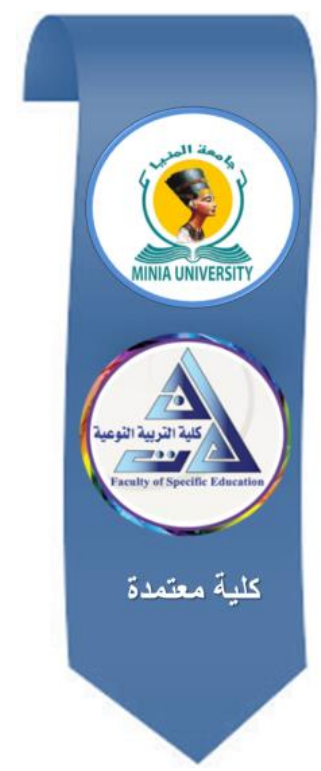

مجلة البحوث في مجالات التربية التوعية

معرف البحث الرقمي DOI: 10.21608/jedu.2020.39962.1049

المجلد السادس العدد 28 ـ مايو 2020

$$
\text { الترقيم الدولي - التي }
$$

\title{
P-ISSN: 1687-3424
}

E- ISSN: 2735-3346

https://jedu.journals.ekb.eg/ موقع المجلة عبر بنك المعرفة المصري http://jrfse.minia.edu.eg/Hom

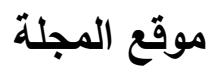
العنوان: كلية التربية النوعية ـ جامعة المنيا ـ جمهورية مصر العربية

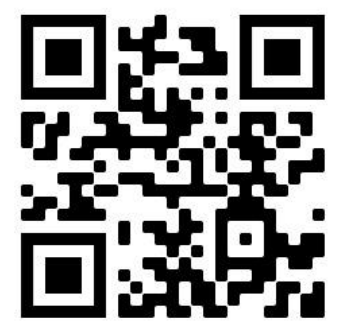


مجلة البحوث فى مجالات التربية النوعية 


\section{Abstract}

\section{Chemical and Nutraceutical Studies of Obese Rats Using Rhubarb and Astragalus Herbs}

This investigation aimed to evaluate the effect of Rhubarb, Astragalus and Mixture of both on male obese rats. Thirty (30) adult male Sprague Dawley rats were divided into five groups. Group (1): Normal rats fed on basal diet as control negative (C-), Group (2): Control positive $(\mathrm{C}+)$ (untreated group). Group (3): Obese rats fed on basal diet and rhubarb (5\%).Group (4): Obese rats fed on basal diet and astragalus (5\%). Group (5): Obese rats fed on basal diet and mixture of both $(5 \%)$. At the end of experiment, after 28 days of feeding, all serum samples were analyzed for biochemical parameters. Obese rats caused a significant decrease in the level of $\mathrm{Hb}, \mathrm{Ht}, \mathrm{RBC}, \mathrm{WBC}$, Neutrophils, Lymphocytes, Monocytes, Eosinphils and Basophils while a significant increase was recorded in TC, TG, VLDL, LDL, AI, U.A, Creatinine, Urea, GOT, GPT, ALP, Glucose and Plt. Obese rats treated with various diets, showed the improvement in all previous parameters.

Key words: Obesity, Rhubarb, Astragalus and Mixture of both.

\section{Introduction}

Rhubarb is a collective name of various perennial plants of the genus Rheum L. from Polygonaceae family. This plant has important economic value, not only referred to a few edible rhubarbs (Yi, 2010), but also used as purgative drug in China since the third millennium BC (Barceloux, 2009), firstly recorded in Shen Nong's Herbal Classic. Rhubarb has been suggested to exert eliminating heat, purging fire, cooling blood, dispersing blood stasis, dredging collateral antidotal and purgative effects, used to treat constipation, diabetic nephropathy, chronic renal failure, acute pancreatitis, gastrointestinal bleeding and other diseases (Jiao and Du, 2000).

Phytochemical investigation on rhubarb has proved major bioactive ingredients are phenolic compounds in six skeletal type including anthraquinones (physcion` chrysophanol, emodin, aloe- 
emodin and rhein and their glucosides), anthocyanins (cyanidin 3rutinoside and cyanidin 3-glucoside),flavonoids (catechin, quercetin 3-Orhamnoside, quercetin3-O galactoside, and quercetin 3- O-rutinoside), stilbene (trans-rhapontigenin and desoxyrhapontigenin (cis-rhapontigenin, resveratrol and piceatannol) (Gao et al., 2011).

Astragalus is a medicinal herb which has been used in traditional Chinese medicine for many years. Specifically, the root of the plant is made into many different forms of supplements, including liquid extracts, capsules, powders and teas. Its root contains many active plant compounds, which are believed to be responsible for its potential benefits. Saponins, polysaccharides, amino acids, flavonoids, organic acid, glycosides, alkaloid, and trace elements (Shahrajabian et al., 2019).

In Traditional Chinese Medicine, Astragalus considers to use in the treatment of diabetes mellitus, nephritis, leukemia, uterine cancer, besides its tonic agent and diuretic effects. Astragalus polysaccharide, the active component extracted from Astragali radix which is the root of Astragalus membranaceus Bunge. Some uses of astragalus are in kidney and urinary problems, digestion, liver problems, female reproductive system problems, muscular, skin problems, cardiovascular and blood, immune and lymphatic system, nervous system, respiratory system, and for some specific disease. It helps protect the body against various types of stress such as physical and emotional stress. Astragalus root including antiaging properties, and also helping to prevent bone loss. It contains astragalosides (antioxidants), which support the integrity of the respiratory tract. In addition, the polysaccharides found in astragalus are known for their immune supporting properties. Astragalus herb also supports deep immune function by promoting normal levels of specific immune cells and aids in their function. Astragalus appears especially effective when immune function is stressed by environmental or endogenous challenges. Astragali radix, the root of Astragalus membranaceus Bunge, has been reported to exert hepatoprotective effects, antioxidative effects,antiviral activity, anti-oxidative effects, 
مجلة البحوث في مجالات التربية النوعية

anti-hypertensive effects, and immunostimulant properties (Shahrajabian et al., 2019).

\section{Materials and Methods}

Materials:

Rhubarb (Rheum palmatum) and astragalus (Astragalus kahiricus) were obtained dry from herb shop in Cairo, Egypt.

\section{Animals:}

Thirty (30) adult male Sprague Dawley rats, average body weight $(150 \pm 10 \mathrm{~g})$ about 7 weeks old, were used in this study. Rats were obtained from Research Institute of Ophthalmology, Medical Analysis Department, Giza, Egypt.

\section{Methods:}

\section{Basal Diet Composition of Tested Rats:}

The basal diet in the experiment consisted of casein (12\%), corn oil $(10 \%)$, mineral mixture $(4 \%)$, vitamin mixture $(1 \%)$, cellulose $(5 \%)$, chorine chloride $(0.2 \%)$, methionine $(0.3 \%)$ and the remained is corn starch (67.5\%) according to AIN (1993).

To indicate obesity rats fed on high- fat diet (HFD) for 6 weeks according to Liu et al., (2004). The composition of HFD was as follows (\%): Casein 25, Corn oil 1, Saturated fat (shep tail fat) 19, Choline chloride 0.25, Vit- Mix 1, Salt Mix 3.5, Cellulose 5, L. Cystine 0.18, Sucrose 10 and Corn Starch 35.07.

\section{Preparation of Materials:}

All materials were milled to soft powder by using electric grinder and kept in dusky stoppered glass bottles in a cool and dry location till use according to Russo (2001).

\section{Experimental Design and Animal Groups:}

Rats were housed in wire cages under the normal laboratory condition, and were fed on basal diet for a week as an adaptation period. The rats were divided into 5 groups each of 6 rats. All groups of rats were housed in wire cages at room temperature 25 $\mathrm{C}^{0}$, and kept under normal healthy condition. Rats were divided into the following groups:

Group (1): Control negative group (-), in which normal rats were fed on basal diet. 
Group (2): Control positive group (+), in which obese rats were fed on basal diet.

Group (3): Obese rats fed on rhubarb 5\% diet.

Group (4): Obese rats fed on astragalus 5\% diet.

Group (5): Obese rats fed on mixture of both $5 \%$ diet.

\section{Determination of Biochemical Blood Parameters:}

Blood samples were collected after 12 hours fasting at the end of experiment using the abdominal aorta. The rats were scarified under ether anaesthesia. Blood samples were received into in clean dry centrifuge tubes, in which blood was left to clot at room temperature, and then centrifuged for 10 minutes at 3000 r.p.m to separate the serum. Serum was carefully aspirated and transferred into clean cuvette tubes and stored frozen at $-20^{\circ} \mathrm{C}$ for biochemical analysis as described by Schermer (1967). All serum samples were analyzed for determination the following parameters:

Urea was determined according to the enzymatic method of Patton and Crouch (1977), creatinine was determined according to kinetic

method

of Henry (1974) and uric acid was according to the enzymatic colorimetric test of Fossati and Prencipe (1980). Aspartate amino transaminase (AST) and alanine amino transferase (ALT) activities were carried out according to the method of Yound (1975) and Tietz (1976). Alkaline phsphatase (ALP) was determined according to Belfield and Goldberg (1971). Total cholesterol (TC) was determined according to Allain (1974), and high density lipoprotein cholesterol (HDL-c) according to Lopez (1997). The calculation of low density lipoprotein cholesterol (LDL-c) was carried out according to the method of Lee and Nieman (1996), atherogenic index (AI) was calculated according to Kikuchi et al., (1998) and triglycerides as Fossati and Prencipe (1982).Serum glucose determined according to Kalpan (1984).

Statistical Analysis:

The data were statistically analyzed using a computerized Costat Program by one way ANOVA using a Completely Randomized Factorial Design (SAS, 1988) when a significant mean effect was detected, the means were separated with the 
Duncan's Multiple Range Test. Differences between treatments at $\mathrm{P} \leq 0.05$ were considered significant. The results are presented as mean \pm SD.

\section{Results and Discussion:}

Data presented in table (1) illustrate the effect of rhubarb, astragalus and mixture of both on BWG, FI and FER of obese rats. It could be observed that the mean value of $(\mathrm{BWG})$ of control $(+)$ group was higher than control (-) group, being $2.46 \pm 0.001$ and $0.86 \pm 0.009 \mathrm{~g}$ respectively. The best (BWG) level showed for groups 5 (rats fed on basal diet containing 5\% mixture of both) when compared to control (+) group.

It could be noticed that the mean value of FI of control $(+)$ group was higher than control (-) group, being 24.12 \pm 0.009 and $19.75 \pm 0.001 \mathrm{~g}$ respectively. The best (FI) level was showed for group 5 (rats fed on basal diet $+5 \%$ mixture of both) when compared to control (+) group.

Also, data of table (1) observed that the mean value of (FER) of control (+) group was higher than control (-) group, being $0.102 \pm 0.0008$ and $0.044 \pm 0.0002$ respectively. The best FER was shown for group 5 (rats fed on basal diet $+5 \%$ mixture of both) when compared to control (+) group.

$\mathrm{Qu}$ et al., (2001) investigated that compound rhubarb preparation (40 $\mathrm{mg} \cdot 100 \mathrm{~g}-1$ body weight $\mathrm{d}-1$ ) can lower body weight in obese rats. The mechanism might involve the decrease in adipocyte leptin expression.

Zhang et al., (2019) reported the neuroprotective effects of Astragalus polysacharin APS $(20 \mathrm{mg} / \mathrm{kg})$ on diabetes-induced memory impairments in Sprague-Dawley (SD) rats and the reduced body weight.

Table (1): Effect of rhubarb, astragalus and mixture of both on body weight gain (BWG), feed intake (FI) and feed efficiency ratio (FER) of obese rats

\begin{tabular}{|l|c||c||c|}
\hline \multicolumn{1}{|c|}{ Parameters } & $\begin{array}{c}\text { BWG (g) } \\
\text { Mean } \pm \text { SD }\end{array}$ & $\begin{array}{c}\text { FI (g) } \\
\text { Mean } \pm \text { SD }\end{array}$ & $\begin{array}{c}\text { FER (\%) } \\
\text { Mean } \pm \text { SD }\end{array}$ \\
\hline G1: Control - ve & $0.86^{\mathrm{e}} \pm 0.009$ & $19.75^{\mathrm{e}} \pm 0.001$ & $0.044^{\mathrm{d}} \pm 0.0002$ \\
\hline
\end{tabular}


مجلة البحوث فى مجالات التربية النوعية

\begin{tabular}{|l|c||c||c|}
\hline G2: Control $+\mathrm{ve}$ & $2.46^{\mathrm{a}} \pm 0.001$ & $24.12^{\mathrm{a}} \pm 0.009$ & $0.102^{\mathrm{a}} \pm 0.0008$ \\
\hline \hline G3: Rhubarb $(5 \%)$ & $2.01^{\mathrm{b}} \pm 0.007$ & $20.72^{\mathrm{b}} \pm 0.007$ & $0.097^{\mathrm{b}} \pm 0.0003$ \\
\hline G4: Astragalus (5\%) & $1.89^{\mathrm{c}} \pm 0.008$ & $20.64^{\mathrm{c}} \pm 0.005$ & $0.092^{\mathrm{c}} \pm 0.0009$ \\
\hline $\begin{array}{l}\text { G5: } \text { Mixture of both } \\
\text { (5\%) }\end{array}$ & $1.87^{\mathrm{d}} \pm 0.004$ & $20.55^{\mathrm{d}} \pm 0.002$ & $0.091^{\mathrm{c}} \pm 0.0005$ \\
\hline LSD & 0.012 & 0.010 & 0.001 \\
\hline
\end{tabular}

Values in each coloum with different letters are significantly different $(\mathrm{P}<0.05)$.

Data presented in table (2) show the effect of rhubarb, astragalus and mixture of both on total cholesterol and triglycerides of obese rats. It could be observed that the mean value of total cholesterol (TC) of control (+) group was higher than control (-) group, being $206 \pm 2.09$ and $98 \pm 2.75 \mathrm{mg} / \mathrm{dl}$ respectively. The best serum (TC) level showed for groups 5 (rats fed on basal diet containing 5\% mixture of both) when compared to control (+) group.

It could be observed that the mean value of triglycerides TG of control (+) group was higher than control (-) group, being $208 \pm 2.81$ and $97 \pm 2.05 \mathrm{mg} / \mathrm{dl}$ respectively. The best serum (TG) level was showed for group 5 (rats fed on basal diet $+5 \%$ mixture of both) when compared to control (+) group.

Gholami et al., (2015) found that extract of rhubarb at doses of 666 and $1000 \mathrm{mg} / \mathrm{kg} \mathrm{BW}$ decreases the total cholesterol in rats fed high cholesterol diet.

Chen et al., (2018) reported that astragalus polysaccharides (APS) reduced total cholesterol and triglycerides in hyperlipidemic rats.

Table (2): Effect of rhubarb, astragalus and mixture of both on total cholesterol (TC) and triglycerides (TG) of obese rats

\begin{tabular}{|l|c|c|}
\hline \multicolumn{1}{|c|}{ Parameters } & $\begin{array}{c}\text { TC }(\text { mgldl) } \\
\text { Mean } \pm \text { SD }\end{array}$ & $\begin{array}{c}\text { TG(mgldl) } \\
\text { Mean } \pm \text { SD }\end{array}$ \\
\hline Groups & $98^{\mathrm{d} \pm 2.75}$ & $97^{\mathrm{e}} \pm 2.05$ \\
\hline G2: Control $-\mathrm{ve}$ & $206^{\mathrm{a}} \pm 2.09$ & $208^{\mathrm{a}} \pm 2.81$ \\
\hline
\end{tabular}


مجلة البحوث في مجالات التربية النوعية

\begin{tabular}{|l|c|c|}
\hline G3: Rhubarb (5\%) & $117^{\mathrm{b}} \pm 2.62$ & $143^{\mathrm{b}} \pm 2.95$ \\
\hline G4: Astragalus (5\%) & $105^{\mathrm{c}} \pm 2.19$ & $118^{\mathrm{c}} \pm 2.63$ \\
\hline G5: Mixture of both $(5 \%)$ & $91^{\mathrm{e}} \pm 2.24$ & $102^{\mathrm{d}} \pm 2.54$ \\
\hline LSD & 4.35 & 4.76 \\
\hline
\end{tabular}

Values in each coloum with different letters are significantly different $(\mathrm{P}<0.05)$.

Data presented in table (3) illustrate the effect of rhubarb, astragalus and mixture of both on HDLc, LDLc, VLDLc \& AI of obeses rats.

It could be noticed that the mean value of $\left(\mathrm{VLDL}_{\mathrm{C}}\right)$ of control (+) group was higher than control (-) group, being $41.6 \pm 1.26$ and $19.4 \pm 1.15 \mathrm{mg} / \mathrm{dl}$ respectively. The best serum VLDLc was shown for group 5 (rats fed on basal diet $+5 \%$ mixture of both) when compared to control (+) group.

It could be shown that the mean value of (HDLc) of control (-) group was higher than control (+) group, being 52 \pm 1.11 and $35 \pm 2.77 \mathrm{mg} / \mathrm{dl}$ respectively. The best serum HDLc was shown for group 5 (rats fed on basal diet containing 5\% mixture of both) when compared to control (+) group.

The same table indicated that the mean value of (LDLc) of control (+) group was higher than control (-) group, being $129.4 \pm 0.93$ and $26.6 \pm 1.22 \mathrm{mg} / \mathrm{dl}$ respectively. The best serum LDLc was shown for group 5 (rats fed on basal diet $+5 \%$ mixture of both) when compared to control (+) group.

Also, data of table (4) observed that the mean value of (AI) of control (+) group was higher than control (-) group, being $4.89 \pm 0.009$ and $0.89 \pm 0.001$ respectively. The best AI was shown for group 5 (rats fed on basal diet $+5 \%$ mixture of both) when compared to control (+) group.

Wang et al., (2015) indicated that rhubarbs from different regions reduced low density lipoprotein and increased high density lipoprotein of hyperlipidemia rats.

Chen et al., (2018) reported that astragalus polysaccharides (APS) at $700 \mathrm{mg} /(\mathrm{kg} \cdot \mathrm{d})$ for 8 weeks reduced low density 
مجلة البحوث في مجالات التربية النوعية

lipoprotein and increased high density lipoprotein in hyperlipidemic rats.

Table (3): Effect of rhubarb, astragalus and mixture of both on (VLDLc), (HDLc), (LDLc) (mg/dl) and Atherogenic index (AI) of obese rats

\begin{tabular}{|l|c|c|c|c||}
\hline \multicolumn{1}{|c|}{ Parameters } & $\begin{array}{c}\text { VLDL } \\
(\mathbf{m g} / \mathbf{d l}) \\
\text { Mean } \pm \text { SD }\end{array}$ & $\begin{array}{c}\text { HDL } \\
(\mathbf{m g} / \mathbf{d l}) \\
\text { Mean } \pm \text { SD }\end{array}$ & $\begin{array}{c}\text { LDL } \\
(\mathbf{m g} / \mathbf{d l}) \\
\text { Mean } \pm \text { SD }\end{array}$ & $\begin{array}{c}\text { AI } \\
\text { Mean } \pm \text { SD }\end{array}$ \\
\hline $\begin{array}{l}\text { G1: } \\
\text { Control -ve }\end{array}$ & $19.4^{\mathrm{d}} \pm 1.15$ & $52^{\mathrm{a}} \pm 1.11$ & $26.6^{\mathrm{d}} \pm 1.22$ & $0.89^{\mathrm{e}} \pm 0.001$ \\
\hline $\begin{array}{l}\text { G2: } \\
\text { Control +ve }\end{array}$ & $41.6^{\mathrm{a}} \pm 1.26$ & $35^{\mathrm{d}} \pm 2.77$ & $129.4^{\mathrm{a}} \pm 0.93$ & $4.89^{\mathrm{a}} \pm 0.009$ \\
\hline $\begin{array}{l}\text { G3: } \text { Rhubarb } \\
(\mathbf{5 \%})\end{array}$ & $28.6^{\mathrm{b}} \pm 1.48$ & $41^{\mathrm{c}} \pm 1.58$ & $47.4^{\mathrm{b}} \pm 0.88$ & $1.85^{\mathrm{b}} \pm 0.005$ \\
\hline $\begin{array}{l}\text { G4: Astragalus } \\
(5 \%)\end{array}$ & $23.6^{\mathrm{c}} \pm 1.72$ & $47^{\mathrm{b}} \pm 1.42$ & $34.4^{\mathrm{c}} \pm 1.29$ & $1.23^{\mathrm{c}} \pm 0.002$ \\
\hline $\begin{array}{l}\text { G5: } \\
\text { Mixture of } \\
\text { both }(5 \%)\end{array}$ & $20.4^{\mathrm{d}} \pm 1.48$ & $48^{\mathrm{b}} \pm 1.39$ & $22.6^{\mathrm{a}} \pm 0.97$ & $0.90^{\mathrm{d}} \pm 0.006$ \\
\hline \hline LSD & 2.60 & 3.19 & 1.95 & 0.009 \\
\hline
\end{tabular}

Values in each coloum with different letters are significantly different $(\mathrm{P}<0.05)$.

Data of table (4) indicate the effect of rhubarb, astragalus and mixture of both on serum levels of AST, ALT, ALP enzymes $\&$ (AST/ALT) ratio of obese rats.

It could be observed that the mean value of AST enzyme of control (+) group was higher than control (-) group, being 49 \pm 1.25 and $30 \pm 0.98$ (U/L) respectively. The best treatment was observed for group 5 (basal diet containing $5 \%$ mixture of both) when compared to control (+) group.

It could be noticed that the mean value of ALT enzyme of control (+) group was higher than control (-) group, being $102 \pm 1.83$ and $28 \pm 0.25$ (U/L) respectively. The best treatment was observed for group 5 (basal diet containing $5 \%$ mixture of both) when compared to control (+) group.

Data of the same table (4) show the mean value of ALP enzyme of control (+) group was higher than control (-) group, 
being $256 \pm 1.81$ and $177 \pm 1.08$ (U/L) respectively. Group 5 showed the lowest mean value of ALP enzyme level as compared to control (+) group which and recorded the best result.

Also, it could be noticed that the mean value of (AST/ALT) of control (-) group was higher than control (+) group, being $1.07 \pm 0.007$ and $0.48 \pm 0.004$ respectively. The best treatment was observed for group 5 when compared to control (+) group.

Dang et al., (2008) reported that odin and astragalus polysaccharides (APS) in a rat model of chronic hepatic injury reduced aspartate aminotransferase (AST) and alanine aminotransferase (ALT).

Chen et al., (2009) found that (3', 5-dihydroxy-4'methoxystilbene 3-Obeta-D-glucopyranoside) from extracts of rhubarb rhizomes decreased aspartate aminotransferase (AST) and alanine aminotransferase (ALT) in streptozotocin (STZ)-induced type 1 diabetic rats.

Table (4): Effect of rhubarb, astragalus and mixture of both on AST, ALT, AST/ALT and ALP (U/L) of obese rats

\begin{tabular}{|l||c|c|c|c||}
\hline Parameters & $\begin{array}{c}\text { AST } \\
\text { (U/L) } \\
\text { Mean } \pm \text { SD }\end{array}$ & $\begin{array}{c}\text { ALT } \\
\text { (U/L) } \\
\text { Mean } \pm \text { SD }\end{array}$ & $\begin{array}{c}\text { AST/ALT } \\
\text { Mean } \pm \text { SD }\end{array}$ & $\begin{array}{c}\text { ALP } \\
(\mathbf{U} / \mathbf{L}) \\
\text { Mean } \pm \text { SD }\end{array}$ \\
\hline $\begin{array}{l}\text { G1: } \\
\text { Control -ve }\end{array}$ & $30^{\mathrm{e}} \pm 0.89$ & $28^{\mathrm{e}} \pm 0.25$ & $1.07^{\mathrm{a}} \pm 0.007$ & $177^{\mathrm{d}} \pm 1.08$ \\
\hline $\begin{array}{l}\text { G2: } \\
\text { Control +ve }\end{array}$ & $49^{\mathrm{a}} \pm 1.26$ & $102^{\mathrm{a}} \pm 1.83$ & $0.48^{\mathrm{c}} \pm 0.004$ & $265^{\mathrm{a}} \pm 1.81$ \\
\hline $\begin{array}{l}\text { G3: Rhubarb } \\
(5 \%)\end{array}$ & $36^{\mathrm{b}} \pm 0.76$ & $35^{\mathrm{b}} \pm 0.42$ & $1.03^{\mathrm{b}} \pm 0.003$ & $204^{\mathrm{b}} \pm 1.62$ \\
\hline $\begin{array}{l}\text { G4: } \\
\begin{array}{l}\text { Astragalus } \\
(5 \%)\end{array}\end{array}$ & $34^{\mathrm{c}} \pm 0.33$ & $33^{\mathrm{c}} \pm 0.58$ & $1.03^{\mathrm{b}} \pm 0.006$ & $200^{\mathrm{c}} \pm 1.25$ \\
\hline $\begin{array}{l}\text { G5: } \\
\text { Mixture of } \\
\text { both }(5 \%)\end{array}$ & $32^{\mathrm{d}} \pm 0.22$ & $30^{\mathrm{d}} \pm 0.36$ & $1.07^{\mathrm{a}} \pm 0.009$ & $199^{\mathrm{c}} \pm 1.76$ \\
\hline $\begin{array}{l}\text { LSD } \\
\text { LSD }\end{array}$ & 1.43 & 1.64 & 0.011 & 2.79 \\
\hline
\end{tabular}

Values in each coloum with different letters are significantly different $(\mathrm{P}<0.05)$.

Data presented in table (5) show the effect of rhubarb, astragalus and mixture of both on serum glucose of diabetic rats. It 
could be noticed that the mean value of glucose of control (+) group was higher than control (-) group, being 296 \pm 3.74 and $135 \pm 1.89(\mathrm{mg} / \mathrm{dl})$ respectively. The best serum glucose was observed for group 5 (basal diet containing 5\% mixture of both) when compared to control (+) group.

Shokri et al., (2015) investigated that hydroalcoholic extract of rhubarb root reduced serum glucose of diabetic rats.

Dun et al., (2016) found that astragalus polysaccharides (APS) after 8-week reduced serum fasting glucose in diabetic rats.

Table (5): Effect of rhubarb, astragalus and mixture of both on serum glucose $(\mathrm{mg} / \mathrm{dl})$ of obese rats

\begin{tabular}{|l|c|}
\hline \multicolumn{1}{|c|}{ Parameters } & $\begin{array}{c}\text { Glucose } \\
\text { (mg/d) } \\
\text { Mean } \pm \text { SD }\end{array}$ \\
\hline Groups & $135^{\mathrm{d}} \pm 1.89$ \\
\hline G1: Control $-\mathrm{ve}$ & $296^{\mathrm{a}} \pm 3.74$ \\
\hline \hline G3: Rhubarb (5\%) & $158^{\mathrm{b}} \pm 1.36$ \\
\hline G4: Astragalus $(5 \%)$ & $141^{\mathrm{c}} \pm 1.61$ \\
\hline G5: mixture of both $(5 \%)$ & $138^{\mathrm{cd}} \pm 1.81$ \\
\hline LSD & 3.77 \\
\hline
\end{tabular}

Values in each coloum with different letters are significantly different $(\mathrm{P}<0.05)$.

Results of table (6) show the mean value of serum creatinine, urea and uric acid ( $\mathrm{mg} / \mathrm{dl})$ on obese rats fed on various diets.

It could be observed that the mean value of uric acid of control (+) group was higher than control (-) group, being $6.87 \pm 0.001$ and $2.31 \pm 0.004 \mathrm{mg} / \mathrm{dl}$ respectively. Group 5 (basal diet containing $5 \%$ mixture of both) recorded the best result as compared to control (+) group.

The same table (6) results illustrate that mean value of creatinine of control (+) group was higher than control (-) group, being $1.74 \pm 0.005$ and $0.52 \pm 0.002 \mathrm{mg} / \mathrm{dl}$ respectively. In concern to creatinine the best treatment was recorded for the group 5 (rats fed on basal diet $+5 \%$ mixture of both) when compared to control 
(+) group.

It could be noticed that the mean value of urea of control $(+)$ group was higher than control (-) group, being $62 \pm 1.68$ and $29 \pm 1.89 \mathrm{mg} / \mathrm{dl}$ respectively. Group 5 (rats fed on basal diet $+5 \%$ mixture of both) recorded the best result as compared to control (+) group.

Xiao et al., (2015) found that astragalus saponin extracts (AS) reduced serum creatinine (Scr) and uric acid (UA) in diabetic rats induced by streptozotocin (STZ).

Deng et al., (2018) reported that rhubarb reduced serum creatinine in the renal toxicity of rats.

Table (6): Effect of rhubarb, astragalus and mixture of both on uric acid (U.A), creatinine and urea $(\mathrm{mg} / \mathrm{dl})$ of obese rats

\begin{tabular}{|l|c|c|c||}
\hline \multicolumn{1}{|c|}{ Parameters } & $\begin{array}{c}\text { U.A } \\
(\mathbf{m g} / \mathbf{d l}) \\
\text { Mean } \pm \text { SD }\end{array}$ & $\begin{array}{c}\text { Creatinine } \\
(\mathbf{m g} / \mathbf{d l}) \\
\text { Mean } \pm \text { SD }\end{array}$ & $\begin{array}{c}\text { Urea } \\
(\mathbf{m g} / \mathbf{d l}) \\
\text { Mean } \pm \text { SD }\end{array}$ \\
\hline G1: Control $-\mathrm{ve}$ & $2.31^{\mathrm{e}} \pm 0.004$ & $0.52^{\mathrm{e}} \pm 0.002$ & $29^{\mathrm{d}} \pm 1.89$ \\
\hline G2: Control +ve & $6.87^{\mathrm{a}} \pm 0.001$ & $1.74^{\mathrm{a}} \pm 0.005$ & $62^{\mathrm{a}} \pm 1.68$ \\
\hline G3: Rhubarb (5\%) & $5.92^{\mathrm{b}} \pm 0.008$ & $0.75^{\mathrm{b}} \pm 0.007$ & $45^{\mathrm{b}} \pm 1.06$ \\
\hline $\begin{array}{l}\text { G4: } \text { Astragalus } \\
\text { (5\%) }\end{array}$ & $5.87^{\mathrm{c}} \pm 0.006$ & $0.73^{\mathrm{c}} \pm 0.003$ & $43^{\mathrm{b}} \pm 1.15$ \\
\hline $\begin{array}{l}\text { G5: } \text { Mixture of } \\
\text { both }(5 \%)\end{array}$ & $5.20^{\mathrm{d}} \pm 0.009$ & $0.61^{\mathrm{d}} \pm 0.001$ & $37^{\mathrm{c}} \pm 1.34$ \\
\hline LSD & 0.011 & 0.008 & 2.65 \\
\hline
\end{tabular}

Values in each coloum with different letters are significantly different $(\mathrm{P}<0.05)$.

Data presented in table (7) show the effect of rhubarb, astragalus and mixture of both on $\mathrm{Hb}, \mathrm{Ht}, \mathrm{RBC}, \mathrm{PLt}$ and $\mathrm{WBC}$ of obese rats.

It could be observed that the mean value of $(\mathrm{Hb})$ of control (-) group was higher than control (+) group, being 19.80 \pm 0.009 and $12.87 \pm 0.002 \mathrm{~g} / \mathrm{dl}$ respectively. The best $\mathrm{Hb}$ was shown for 
group 5 (rats fed on basal diet $+5 \%$ mixture of both) when compared to control (+) group.

It could be observed that the mean value of (Ht) of control

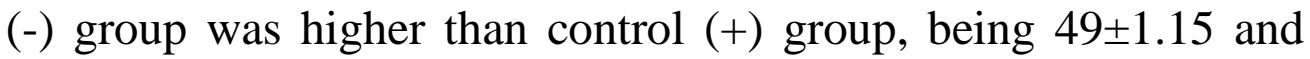
$39 \pm 1.78 \%$ respectively. The best $\mathrm{Ht}$ was shown for group 4,5 (rats fed on basal diet containing 5\% astragalus and mixture of both) when compared to control (+) group.

The same table indicated that the mean value of (RBC) of control (-) group was higher than control (+) group, being $5 \pm 0.25$ and $3 \pm 0.25\left(10^{6} / \mu \mathrm{L}\right)$ respectively. The best RBC was shown for group 4, 5 (rats fed on basal diet $+5 \%$ astragalus and mixture of both) when compared to control (+) group.

Also, data of table (7) observed that the mean value of (Plt) of control (+) group was higher than control (-) group, being $618 \pm 2.71$ and $446 \pm 0.89\left(10^{3} / \mu \mathrm{L}\right)$ respectively. The best AI was shown for group 5 (rats fed on basal diet $+5 \%$ mixture of both) when compared to control (+) group.

It could be noticed that the mean value of (WBC) of control (-) group was higher than control (+) group, being $10.7 \pm 0.07$ and $7 \pm 0.35\left(10^{3} / \mu \mathrm{L}\right)$ respectively. Group 5 (rats fed on basal diet $+5 \%$ mixture of both) recorded the best result as compared to control (+) group.

Lv et al., (2005) reported that Astragalus membranaceus injection (AMI) $(500 \mathrm{mg} / \mathrm{kg}, 1000 \mathrm{mg} / \mathrm{kg})$ increased red blood cells and hemoglobin on hematopoiesis in anemic mice.

Zhang et al., (2016) found that butanol extract of rheum from rhubarb increased hematocrit and red blood cell count of chronic renal failure in rats.

Table (7): Effect of rhubarb, astragalus and mixture of both on Hb, Ht, RBC, PLT and WBC of obese rats

\begin{tabular}{|c|c|c|c|c|c|}
\hline $\begin{array}{r}\text { Paramete } \\
\text { Groups }\end{array}$ & $\begin{array}{l}\text { Hb }(\mathrm{g} / \mathrm{dl}) \\
\text { Mean } \\
\pm \text { SD }\end{array}$ & $\begin{array}{l}\text { Ht }(\%) \\
\text { Mean } \\
\pm \text { SD }\end{array}$ & \begin{tabular}{l}
\multicolumn{1}{c}{ RBC } \\
$\left(10^{6} / \mu L\right)$ \\
Mean \\
+ SD
\end{tabular} & $\begin{array}{c}\text { PLT } \\
\left(10^{3} / \mu L\right) \\
\text { Mean } \pm \text { SD }\end{array}$ & \begin{tabular}{l}
\multicolumn{1}{c}{ WBC } \\
$\left(10^{3} / \mu L\right)$ \\
Mean \\
\pm SD
\end{tabular} \\
\hline $\begin{array}{l}\text { G1: } \\
\text { Control - } \\
\text { ve }\end{array}$ & $\begin{array}{c}19.80^{\mathrm{a}} \pm \\
0.009\end{array}$ & $\begin{array}{c}49^{\mathrm{b}} \pm 1.1 \\
5\end{array}$ & $5.0^{\mathrm{a}} \pm 0.25$ & $446^{\mathrm{d}} \pm 0.89$ & $10.7^{b} \pm 0.07$ \\
\hline
\end{tabular}


مجلة البحوث فى مجالات التربية النوعية

\begin{tabular}{|l|c|c|c|c|c||}
\hline G2: & $12.87^{\mathrm{e}} \pm$ & $39^{\mathrm{d}} \pm 1.7$ & $3.0^{\mathrm{c}} \pm 0.25$ & $618^{\mathrm{a}} \pm 2.71$ & $7.0^{\mathrm{d}} \pm 0.35$ \\
$\begin{array}{l}\text { Control+v } \\
\text { e }\end{array}$ & 0.002 & 8 & & & \\
\hline G3: & $17.73^{\mathrm{d}} \pm$ & $43^{\mathrm{c}} \pm$ & $4.4^{\mathrm{b}} \pm 0.09$ & $510^{\mathrm{b}} \pm 1.16$ & $9.5^{\mathrm{c}} \pm 0.08$ \\
$\begin{array}{l}\text { Rhubarb } \\
(5 \%)\end{array}$ & 0.001 & 1.65 & & & \\
\hline $\begin{array}{l}\text { G4: } \\
\begin{array}{l}\text { Astragalus } \\
(5 \%)\end{array}\end{array}$ & $\begin{array}{c}18.80^{\mathrm{c}} \pm \\
0.007\end{array}$ & $\begin{array}{c}57^{\mathrm{a}} \pm \\
1.59\end{array}$ & $4.8^{\mathrm{a}} \pm 0.04$ & $450^{\mathrm{c}} \pm 0.62$ & $11.0^{\mathrm{ab}} \pm 0.4$ \\
\hline $\begin{array}{l}\text { G5: } \\
\text { Mixture of } \\
\text { both }(5 \%)\end{array}$ & $\begin{array}{c}18.84^{\mathrm{b}} \pm \\
0.005\end{array}$ & $\begin{array}{c}57^{\mathrm{a}} \pm \\
1.33\end{array}$ & $4.8^{\mathrm{a}} \pm 0.01$ & $448^{\mathrm{cd}} \pm 0.54$ & $11.3^{\mathrm{a}} \pm 0.02$ \\
\hline LSD & 0.01 & 2.76 & 0.29 & & \\
\hline
\end{tabular}

Values in each coloum with different letters are significantly different $(\mathrm{P}<0.05)$.

Data presented in table (8) illustrate the effect of rhubarb, astragalus and mixture of both on Neutrophils, Lymphocytes, Monocytes, Eosinophils and Basophils $\left(10^{9} / \mathrm{L}\right)$ of obese rats.

It could be noticed that the mean value of (Neutrophils) of control (-) group was higher than control (+) group, being $4.51 \pm 0.009$ and $2.95 \pm 0.001$ respectively. The best Neutrophils was shown for group 5 (rats fed on basal diet $+5 \%$ mixture of both) when compared to control (+) group.

It could be observed that the mean value of (Lymphocytes) of control (-) group was higher than control (+) group, being $4.97 \pm 0.009$ and 3.25 \pm 0.002 respectively. The best Lymphocytes was shown for group 5 (rats fed on basal diet containing 5\% mixture of both) when compared to control (+) group.

The same table revealed that the mean value of (Monocytes) of control (-) group was higher than control (+) group, being $1.02 \pm 0.001$ and $0.67 \pm 0.008$ respectively. The best Monocytes was shown for group 5 (rats fed on basal diet $+5 \%$ mixture of both) when compared to control (+) group.

Also, data of table (9) showed that the mean value of (Eosinophils) of control (-) group was higher than control (+) group, being $0.15 \pm 0.002$ and $0.10 \pm 0.009$ respectively. The best Eosinophils was shown for group 4 (rats fed on basal diet $+5 \%$ astragalus) when compared to control (+) group. 
It could be noticed that the mean value of (Basophils) of control (-) group was higher than control (+) group, being $0.06 \pm 0.006$ and $0.04 \pm 0.009$ respectively. Group 4, 5 (rats fed on basal diet $+5 \%$ astragalus and mixture of both) recorded the best result as compared to control (+) group.

It may be concluded that both rhubarb and astragalus 5\% diets, within about 1 month of feeding could combat the side effects induced by obesity.

Table (8): Effect of rhubarb, astragalus and mixture of both on

Neutrophils, Lymphocytes, Monocytes, Eosinophils and Basophils $\left(10^{9} / \mathrm{L}\right)$ of obese rats

\begin{tabular}{|c|c|c|c|c|c|}
\hline $\begin{array}{r}\text { Paramete } \\
\text { rs } \\
\text { Groups }\end{array}$ & $\begin{array}{l}\text { Neutrop } \\
\text { hils } \\
\text { Mean } \pm \\
\text { SD } \\
\end{array}$ & $\begin{array}{l}\text { Lympho } \\
\text { cytes } \\
\text { Mean } \pm \\
\text { SD } \\
\end{array}$ & $\begin{array}{l}\text { Monocytes } \\
\text { Mean } \pm \text { SD }\end{array}$ & $\begin{array}{c}\text { Eosinop } \\
\text { hils } \\
\text { Mean } \pm \\
\text { SD } \\
\end{array}$ & $\begin{array}{l}\text { Basophils } \\
\text { Mean } \pm \text { SD }\end{array}$ \\
\hline $\begin{array}{l}\text { G1: } \\
\text { Control - } \\
\text { ve }\end{array}$ & $\begin{array}{c}4.51^{\mathrm{a}} \pm \\
0.009\end{array}$ & $\begin{array}{c}4.97^{\mathrm{c}} \pm 0 \\
009\end{array}$ & $\begin{array}{l}1.02^{\mathrm{c}} \pm \\
0.001\end{array}$ & $\begin{array}{c}0.15^{\mathrm{a}} \pm \\
0.002\end{array}$ & $\begin{array}{c}0.06^{\mathrm{a}} \pm \\
0.006\end{array}$ \\
\hline $\begin{array}{l}\text { G2: } \\
\text { Control+v } \\
\text { e }\end{array}$ & $\begin{array}{l}2.95^{\mathrm{c}} \pm \\
0.001\end{array}$ & $\begin{array}{c}3.25^{\mathrm{e}} \pm 0 . \\
002\end{array}$ & $\begin{array}{c}0.67^{\mathrm{e}} \pm \\
0.008\end{array}$ & $\begin{array}{l}0.10^{\mathrm{c}} \pm \\
0.009\end{array}$ & $\begin{array}{c}0.04^{\mathrm{b}} \pm \\
0.009\end{array}$ \\
\hline $\begin{array}{l}\text { G3: } \\
\text { Rhubarb } \\
(5 \%)\end{array}$ & $\begin{array}{c}4.0^{b} \pm 0.2 \\
5\end{array}$ & $\begin{array}{c}4.41^{\mathrm{d}} \pm 0 . \\
008\end{array}$ & $\begin{array}{l}0.90^{\mathrm{d}} \pm \\
0.005\end{array}$ & $\begin{array}{c}0.13^{\mathrm{b}} \pm \\
0.001\end{array}$ & $\begin{array}{c}0.06^{\mathrm{a}} \pm \\
0.001\end{array}$ \\
\hline $\begin{array}{l}\text { G4: } \\
\text { Astragalus } \\
(5 \%) \\
\end{array}$ & $\begin{array}{l}4.63^{\mathrm{a}} \pm \\
0.006\end{array}$ & $\begin{array}{c}5.10^{b} \pm 0 \\
005\end{array}$ & $\begin{array}{l}1.05^{\mathrm{b}} \pm \\
0.004\end{array}$ & $\begin{array}{l}0.15^{\mathrm{a}} \pm \\
0.005\end{array}$ & $\begin{array}{c}0.07^{\mathrm{a}} \pm \\
0.008\end{array}$ \\
\hline $\begin{array}{l}\text { G5: } \\
\text { mixture of } \\
\text { both } 5 \% \\
\end{array}$ & $\begin{array}{l}4.76^{\mathrm{a}} \pm \\
0.004\end{array}$ & $\begin{array}{c}5.24^{\mathrm{a}} \pm 0 \\
007\end{array}$ & $\begin{array}{l}1.07^{\mathrm{a}} \pm \\
0.007\end{array}$ & $\begin{array}{l}0.10^{\mathrm{c}} \pm \\
0.008\end{array}$ & $\begin{array}{l}0.07^{\mathrm{a}} \pm \\
0.004\end{array}$ \\
\hline LSD & 0.20 & $\overline{c 0.01}$ & $\overline{0.01}$ & $\overline{0.012}$ & 0.011 \\
\hline
\end{tabular}

Values in each coloum with different letters are significantly different $(\mathrm{P}<0.05)$. 


\section{References:}

Allain, C.C. (1974). Cholesterol enzymatic colorimetric method. J. Clin. Chem., (20): 470.

American Institute of Nutrition (AIN) (1993). Purified diet for laboratory rodent; final report. J. Nutrition, 123:1939-1951.

Barceloux, D. G. (2009). Rhubarb and oxalosis (Rheum species). Disease-a-Month, 6(55): 403-411.

Belfield, A. and Goldberg, D.M. (1971). Alkaline phosphatase colorimetric method. J. of Enzyme, (12):561.

Chen, J.; Ma, M.; Lu, Y.; Wang, L.; Wu, C. and Duan, H. (2009). Rhaponticin from rhubarb rhizomes alleviates liver steatosis and improves blood glucose and lipid profiles in KK/Ay diabetic mice. Planta Medica, 75(05): 472-477.

Chen, S.; Yuan, Q.; Wang, Y. and Yang, Z. (2018). Effect of astragalus polysaccharides on glucose and lipid metabolism and pathological changes of pancreas in rats with hyperlipidemia. Journal of Guangdong Pharmaceutical University, (4): 13.

Dang, S.S.; Zhang, X.; Jia, X.L.; Cheng, Y.A.; Ping, S.; Liu, E. Q. and Li, Z. F. (2008). Protective effects of emodin and astragalus polysaccharides on chronic hepatic injury in rats. Chinese Medical Journal, 121(11), 1010-1014.

Deng, N.; Yi, Y.; Liang, A. H.; Li C.Y.; Zhao, Y.; Pan, C. and Tian, J.Z. (2018). Mechanism of nephrotoxicity of rhubarb in rats. China Journal of Chinese Materia Medica, 43(13): 27772783.

Dun, C.; Liu, J.; Qiu, F.; Wu, X.; Wang, Y.; Zhao, Y. and Gu, P. (2016). Effects of astragalus polysaccharides on memory impairment in a diabetic rat model. Neuropsychiatric Disease and Treatment, 12: 1617.

Fossati, P. and Prencipe, L. (1982). Triglyceride enzymatic colorimetric method. J. Clin. Chem., (28): 2077.

Fossatti, P. and Prencipe, L. (1980): Enzymatic colorimetric test of uric acid. J. Clin. Chem., 28:227.

Gao, L.L.; Xu, X.D.; Nan, H.J.; Yang, J.S. and Chen, S.L. (2011). Chemical constituents in Rheum tanguticum. Chinese Traditional and Herbal Drugs, 42(3): 443-446.

Gholami, S.; Mirzaei, A.; Oryan, S. and Hossaeni, S.E. (2015). The Effect of Rhubarb Extracts on Lipid Profile and Oxidative 
Stress in Wistar Male Rats. International Medical Journal, 22:(2).

Henry, R.J. (1974). Clinical Chemistry Principles and Techniques. 2nd Ed., Harper and Publishers, NewYork. Philadelphia.

Jiao, D.H. and Du, S.J. (2000). The Study of Rhubarb. Shanghai Science \& Technology Press, Shanghai, 291.

Kaplan, L.A. (1984). Clinical Chemistry. The C.V. Mosby Co. St Louis. Toronto. Princeton, 1032-1036.

Kikuchi, H.; Onodera, N.; Matsubara, S., Yassudo, E.; Chonan,O.;

Takahashi, R. and Ishikawa, F. (1998). Effect of soy milk on lipid metabolism in aged ovariectomized rats. Bioscience, Biotechnology and Biochemistry, 62(9): 1688 - 1692.

Lee, R. and Nieman, D. (1996). Nutritional Assessment.2nd Ed., Mosby, Missouri,USA.

Liu, M.; Shen, L.; Liu, Y.; Woods, S.C.; Seeley, R.J.; D'Alessio, D. and Tso, P. (2004). Obesity induced by a high-fat diet down regulates apolipoprotein A-IV gene expression in rat hypothalamus. American Journal of PhysiologyEndocrinology and Metabolism., 287(2): 366-370.

Lopez, M.F. (1997). HDL- Cholesterol colorimetric method. J. Clin. Chem., (23): 282-289.

Lv, Y.; Feng, X. and Zhu, B. (2005). Study on effect of Atragalus membranaceus injection on hematopoiesis in anemic mice with myelosuppression. Journal of Chinese Medicinal Materials, 28(9): 791-793.

Patton, C.J. and Crouch, S.R. (1977). Enzymatic determination of urea. J. Anal. Chem., 49: 464- 469.

Qu, X.Y.; Chen, Y.; Jin, H.M.; Jiao, D.H. and Song, H. L. (2001). Experimental study on preventing obesity by compound rhubarb preparation in rats. Chin J Pathophysiol, 17(7): 673675.

Russo, E. (2001). Handbook of Psychotropic Herbs: A Scientific Analysis of Herbal Remedies for Psychiatric Condition. The Howrth Herbal Press, Inc.

SAS (1988). SAS/STAT User's Guide, Release 6.03. Cary, North Carolina: SAS Institute.

Schermer, S. (1967). The Blood Morphology of Laboratory Animal. Longmans, Printed in Great Britain, Green and Co. L.T.d.

Shahrajabian, M. H.; Sun, W. and Cheng, Q. (2019). Astragalus, an ancient medicinal root in traditional Chinese medicine, a gift 
from Silk Road. International Journal of Agriculture and Biological Sciences, 3(06): 27-38.

Shokri, H.; Farokhi, F.; Heidari, R. and Manaffar, R. (2015). The effect of hydroalcoholic extract of rhubarb root on blood glucose and histopathological changes of pancreas in alloxaninduced diabetic rats. Qom University of Medical Sciences Journal, 8(5): 20-26.

Tietz, N.W. (1976). Fundamentals of Clinical Chemistry. Philadelphia. B. W. Standers, P. 243.

Wang, Z. W.; Guo, M.; Ma, D. and Wang, R. Q. (2015). Effects of rhubarbs from different regions on blood lipid and antioxidation of hyperlipidemia rats. Chinese Journal of Applied Physiology, 31(3): 278-281.

Xiao, F.; Hu, Y.G.; Wu, S.N.; Shou, Q.Y.; Cai, Y.Q., Wang, H.M. and Wang, H. (2015). Protective effect of astragalus saponin extracts on kidneys of diabetic rats. China Journal of Chinese Materia Medica, 40(10): 2014-2018.

Yi, H.Y. (2010). Application of Molecular Techniques in The Research of Germplasm Resources of Rheum. Biotechnology Bulletin, 12.

Yound, D.S. (1975). Determination of GOT. J. Clin. Chem., 21: 1- 6. Zhang, G.; Fang, H.; Li, Y.; Xu, J.; Zhang, D.; Sun, Y. and Zhang, H. (2019). Neuroprotective effect of astragalus polysacharin on streptozotocin (STZ)-induced diabetic rats. Medical Science Monitor: International Medical Journal of Experimental and Clinical Research, 25: 135.

Zhang, Z.H.; Vaziri, N. D.; Wei, F.; Cheng, X. L.; Bai, X. and Zhao, Y.Y. (2016). An integrated lipidomics and metabolomics reveal nephroprotective effect and biochemical mechanism of Rheum officinale in chronic renal failure. Scientific Reports, 6: 22151. 


\section{دراسات كيميائية وتغذوية صحية علي الفئران المصابة بالسمنة باستخدام أعشاب الراوند وإلقتاده}

\section{د.مني علي اليماني}

\section{الملخص العريح}

يهرف هذا البحث إلى تقييم تأثيرأعثاب الراوند والقتاده والخليط منهما علي ذكور الفئران المصابة بالسمنة. تم تقسيم ثلاثون فأر من الذكور البالغين سبراغ داولي إلى لى لهاعي

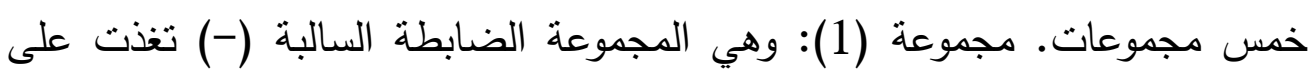
الوجبة الأساسية ، المجموعة (2): وهي المجموعة الضابطة الموجبة (+) وهي الفئران

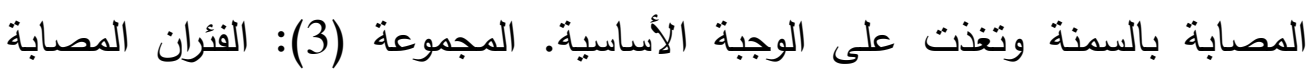
بالسمنة التي تغذت علي نبات الراوند بنسبة 5\% المجموعة (4): الفئران المصابة بالسمنة التي تغذت على نبات القتاده بنسبة 5 \% . المجموعة (5): الفئران المصابة لـابة

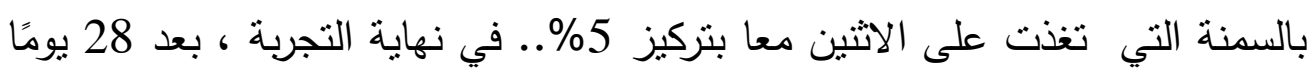

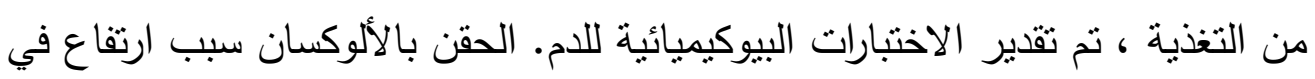

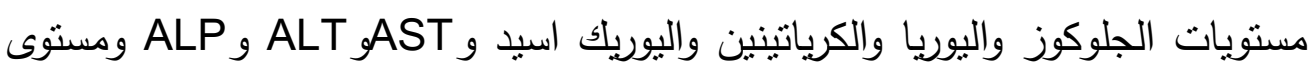
الكوليسترول الكلي وجلسريدات ثناثية والليبوبروتين منخفض الكثافة والليبوبروتين منخفض الكثافة جدا والصفائح الدموية وانخفاض مستويات الليبروتين مرتفع الكثافة

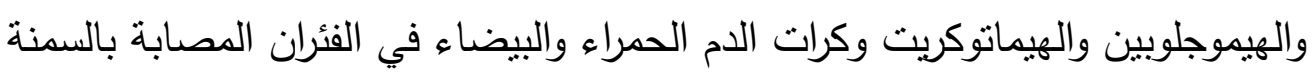
وتحسنت النتائج باستخدام الأغذية المعالجة.

الكلمات المفتاحية : مرض السمنة ، عثبة الراوند ، عثبة القتاده والخليط من الاثثين معا. 